\title{
FOREST DWELLERS AND MICROFINANCE: EMERGENCE AND PROSPECTS (WITH SPECIAL REFERENCE TO KATNI, MANDSOUR AND SHEOPUR DISTRICTS OF MADHYA PRADESH, INDIA)
}

\author{
S. TEKI ${ }^{1}$, B.P. PETHIYA ${ }^{2} \&$ P. BHATTACHARYA ${ }^{2}$ \\ ${ }^{1}$ National Institute of Financial Management, India. \\ ${ }^{2}$ Indian Institute of Forest Management, India.
}

\begin{abstract}
Forest dwellers (FDs) depend on non-wood forest products (NWFPs), such as tamarind, for their survival, growth and socio-economic needs. FDs finance their needs during lean season by taking advances from traders of NWFPs against forward mortgaging of the forthcoming harvest of NWFP. This is called NWFPs advance trade, which is exploitative in nature. FDs do not have access to formal financial systems to finance their needs. Pre-determined pricing on account of advance trading of NWFPs is done lower than the market price of such NWFPs and is known as distress sale of NWFPs. To check this exploitation of FDs by traders, microfinance during the lean season should be extended to the FDs, so that they can wait till an appropriate time to sell their NWFP harvest for better price. This will in turn enable the FDs to adopt value additions at their level to get better price. A study has been conducted in Madhya Pradesh on emerging microfinance practices. Findings of the study indicate that of the total financing undertaken, traders account for $52.8 \%$, relative and friends $20.0 \%$, selfhelp groups (SHGs) $15.4 \%$, while banks and government schemes account for $11.8 \%$. Use based categorization indicates that the main purposes of microfinance to FDs are as follow: health and subsistence account for 23.2 and $21.5 \%$, respectively, followed by marriage purposes at $18.1 \%$ and education at $15.2 \%$. Awareness about SHG movement amongst the FDs is $65.7 \%$. There is a gap between awareness about SHG and membership held by the FDs. Interest rates vary from source to source. Traders charge about 3.83\% per month (p.m.), SHGs $2.2 \%$ p.m. and relatives and friends $2 \%$. Mean size of SHG is 12 members per group, though the maximum can be 20 members. The frequency of SHGs meeting is once in a month, average contribution per member per meeting various from Rs. 10 in some groups up to Rs. 50 in others. Governmental organizations (GOs) and nongovernmental organizations (NGOs) should strengthen SHGs driven microfinance movement to bridge the gap and to increase dissemination of the microfinance movement. The institutional network, microfinance, marketing, technology, infrastructure development and other managerial interventions have to be augmented by all concerned GOs, banks and NGOs, keeping the local socio-economic aspects in mind, for effective and sustainable results.
\end{abstract}

Keywords: forest dwellers, microfinance, NWFPs, SHGs.

\section{INTRODUCTION}

Forest dwellers (FDs) largely depend on non-wood forest products (NWFPs) for their survival and growth needs. The NWFPs play a vital role in the socio-economic life of these people [1]. They finance their needs during the lean season by way of borrowing advance money from moneylenders/ NWFPs traders against the NWFPs to be harvested/collected in forthcoming season, which is called NWFPs advance trade [2]. This kind of NWFPs advance trade (entering into sale contract with traders to receive money before the harvest) seems to be exploitative. The pre-determined price on account of advance trading (indispensable for the FDs to finance subsistence during NWFPs lean period) of the NWFPs is much lower in value than the market value of such NWFPs and this is also called as distress sale of NWFPs. To check this type of exploitation by the NWFPs traders/moneylenders, there should be provision for financial services. This means enabling the forest dweller to access formal financial services, also called as organized sector financial services, such as borrowings and savings 
from banks called microfinancial services. This will enable them to wait till the appropriate time to sell their NWFP harvest. This in turn promotes stock holding capacity of the FDs to think over and adopt some NWFPs value additions at their level to get more price than otherwise.

The rural population in India, including FDs, has been exploited on many fronts, including moneylenders, for ages now [3]. Exploitation under the usury system has been quite substantial and continuous. Microfinance arose during the 1980s as a response to doubts and research findings about the efficiency of the state delivery system in providing subsidized credit to poor farmers. Government and international donors assessed and assumed that the poor required cheap credit and saw this as a way of promoting local people economy [4]. In fact, the FDs who are unable to save for a rainy day, due to one reason or the other, run after moneylenders/NWFP traders to borrow in cash or kind to fulfill their needs, without which they cannot even survive. The FDs earn their bread by way of either self-consumption or selling or through bartering of NWFPs. Varied value additions, lack of logistics and access to financial assistance inhibits value additions on NWFPs. NWFPs are generally collected and sold in raw and unprocessed form, although there can be varied value additions. This in turn results in feeble bargaining power and low returns to the FDs. If the FDs are provided access to microfinancial assistance, it would facilitate value addition for NWFPs apart from mitigating the need for distress sale. This would enable them to store and then sale optimally and reap maximum benefit. Also, it will set the FDs free from the clutches of moneylenders and ruthless channel members (middlemen) in the current distress NWFP trade. The present research study has therefore been conducted to learn the scope of microfinance in the development of NWFP based activities. Microfinance, in simple words, may be defined as financial service for the poor [5]. The amount of money required for financing the needs of FDs may be very small as compared to the general meaning of financing, but the impact of such microfinancing is going to be substantial for generating means of livelihood for the FDs. Accordingly, the present study was conceived to learn the scope of microfinance in the development of NWFP based activities, covering the objectives of: (1) identifying the role of microfinance in general and specifically for forest dwelling community with special reference to NWFPs; (2) documenting existing microfinance initiatives in the study area to support NWFP based activities; (3) exploring the scope of microenterprises and the quantum of microfinance required. The outcome of the study could be useful in policymaking and to the institutions involved in field-level activities relating to microfinance and NWFP, for the betterment of the FDs.

\section{RESEARCH METHODOLOGY}

The present study is an abridged form of a research project entitled "Scope of Microfinance in the development of NWFP based activities: Case studies from Madhya Pradesh (MP)" based on primary and secondary data.

\subsection{Data sources}

Primary data have been collected by way of administering a questionnaire/schedule to the selected respondents from four categories of population, viz. (a) primary collector/villager (FD), (b) local grocery traders, (c) NWFP traders (middlemen) and (d) moneylenders. In addition to this, interactions/discussion with relevant NGOs, revenue department officials, MP Minor Forest Produce Federation (MPMFPF), Bhopal, BASIX (Krishana Bhima Samrudhi Local Area Bank Limited) [6], Hyderabad, SHARE MicroFin Limited, Hyderabad, National Agricultural Bank for Rural Development (NABARD), Bhopal and Forest Department officials of Katni, Mandsour and Sheopur districts were held to source relevant data and inputs. The team visited Narayanganj (Mandsour district) and Neemach agriculture mandis (market). In addition the team benefited from the suggestions of the 
Table 1: Study area-wise sampling details.

\begin{tabular}{lccc}
\hline Name of division & $\begin{array}{c}\text { Number of villages } \\
\text { surveyed }\end{array}$ & $\begin{array}{c}\text { Number of respondents } \\
\text { interviewed/interacted }\end{array}$ & $\begin{array}{c}\text { Number of traders } \\
\text { interviewed/interacted }\end{array}$ \\
\hline Katni & 6 & 57 & 8 \\
Mandsour & 4 & 34 & 6 \\
Sheopur & 4 & 52 & 6 \\
Total & 14 & 143 & 20 \\
\hline
\end{tabular}

respective Indian Institute of Forest Management (IIFM) faculty members. The data collected has been analyzed accordingly.

\subsection{Primary data collection and analysis}

The data collected as mentioned earlier have been processed with the help of necessary statistical tools and measurements. Aspects incorporated in the questionnaire/schedule includes demographic profile, availability of NWFPs, trade, processing, value additions, microfinance requirements and sources, value addition for NWFPs, sources of livelihood and so on. The data were then analyzed and inferences/interpretations drawn. A schedule was also canvassed to various local traders/NWFP traders for obtaining information regarding NWFPs' movement/flow, value additions at their level, function/services rendered by them to the FDs and so on. Analysis of the primary data had been done employing various statistical tools such as arithmetic mean, percentage, graphs, bars, ratio and proportion and so on. The data analysis has been supplemented with interactions with concerned government officers and NGOs. The team also visited Rashtriya Van Mela (National Forest Produce Fair) held at Bhopal during December 2002 to study NWFP trade at a state level fair. All relevant data/opinions sought from these sources have also been incorporated into the report.

\subsection{Sample size}

A total of 14 villages were selected and about 10-15 local individuals (respondents) interviewed from each selected village. This constituted 143 respondents (see Table 1) from the selected villages and 20 local level NWFPs traders/moneylenders, which formed the sample size.

\subsection{Sampling technique}

Random-sampling method was employed to select the individual respondents; judgment sampling technique was used for selecting moneylenders and middlemen. Moreover, mass meetings at village level were also held to solicit voluntary responses from all concerned stakeholders.

\subsection{Geographical area}

The study geographical area consisted of Katni, Mandsour and Sheopur districts of Madhya Pradesh state, and the concerned forest divisions (generally each district has one or two forest divisions) viz. Katni, Mandsour and Sheopur divisions were included in the sample design. From each forest division four to six villages were selected and a total fourteen villages constitute the geographical area of the study (Fig. 1). 


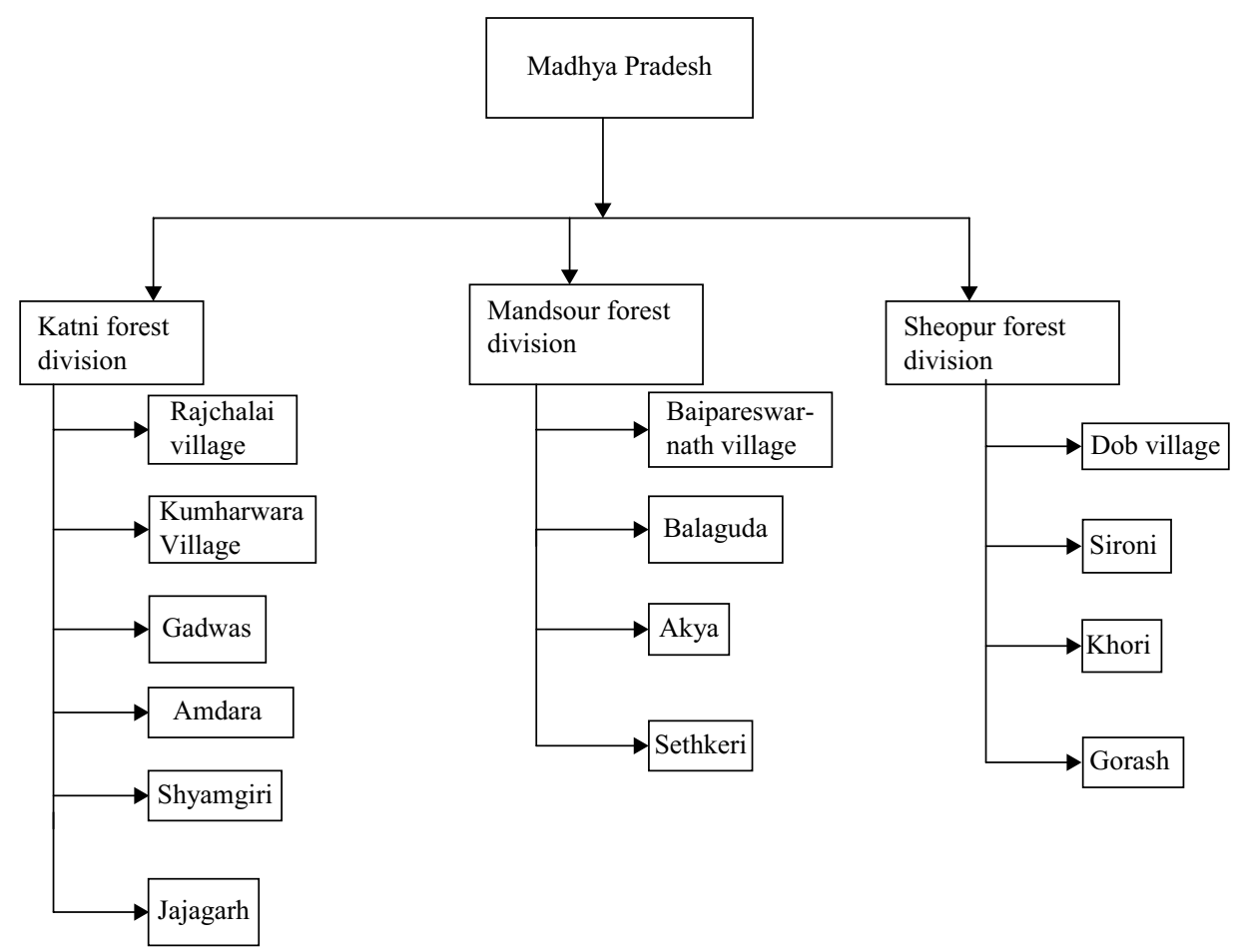

Figure 1: Geographical area of study.

\subsection{Time period}

The research project was awarded in November 2001 the fieldwork commenced in May 2002 and finally completed in July 2003.

\subsection{Justification of geographical area}

The MP state was incorporated into the study area because it is economically poor although it has a rich forest cover and is one of the pioneer states where most of the powers related to NWFPs are now vested with the community. MP is situated in central India occupying an important place for tribal people. It accounts for nearly one-fourth of the total tribal population of India. Madhya Pradesh has nearly 46 tribes [7]; also, it is one of the states apart from Andhra Pradesh where serious efforts have been made to eradicate poverty by DFID and World Bank with government intervention.

Katni and Sheopur forest divisions are selected due to its huge tribal population and thick forest cover. Moreover the lack of infrastructure and communication facilities in these two districts restricts the accessibility of these villages to the growth centers. The Mandsour forest division has been selected as it is rich in medicinal plants that have been specially cultivated, including species such as aswagandh, isopgol and asalia (medicinal herbs that are useful for treating hypertension, piles, etc.). 


\subsection{Secondary data collection and analysis}

The secondary data have been sourced from the internet, forest department records, journals and unpublished reports. Offices of MPMFPF - a government agency for minor forest produce, Bhopal and Sanjeevani (NWFPs) retail outlet, Bhopal - have been visited in person. The library of IIFM, Bhopal, was also a major source of secondary data.

\subsection{Study area profile [8]}

\subsubsection{Mandsour district}

Mandsour is surrounded by the Rajasthan border from one side and on the other side by Neemach, which is famous the world over for its herbs market. The district is rich in archaeological and historical heritage. It is also famous for its large production of opium. The slate pencil industry is the main industry of the district.

The forests of Mandsour district are the southern dry deciduous type. The upper canopy comprises of Dhanda, Khair, Salai, Salar, Opium and so on, the middle canopy is Palash and Karonda while the land over canopy is constituted by Lantana, acacia (Phuwar) and so on. Ponai, Phulera, Anjan are ground flora found in the district. The soil of the forest is made of Malwa clay loam, Mandsour loam and the Laborite type. The presence of salt rock in varying degrees of weathering and decomposition is also seen.

\subsection{Katni district}

The Katni forest division is the biggest production centre of NWFPs in India and it covers mostly all types of NWFPs. Some important medicinal plants found in these forest areas grow naturally in this climate, because the environment of these forests is ideal for medicinal plants. Rocks are mainly sandstone; the soil is sandy and loamy at places mixed with murram and boulders.

The forest type belongs to 5A southern typical dry deciduous, C3 - southern dry mixed deciduous forest, the area bears IVA to IVB quality forest. Forest density of the area varies from 0.2 to 0.5 and the regeneration is inadequate. The area is subjected to very heavy biotic pressure, which is why it has been degrading swiftly. There is heavy to moderate soil corrosion in these areas, which translates into deteriorating productivity of the forest. Due to continuous hacking by villagers only strong coppicers survive.

Natural regeneration in the region is absent. The area is heavily infested with lantana and other weeds. A wide range of plant species grow in the area in different canopies of the forest: but as forest management for timber has been the only purpose of management, the species of NWFPs are not exhaustibly represented in the details of vegetation. Though there are many types of NWFPs found in the forest, it is famous for Anola (Emblica officinalis), Char (Buchanania lanzan), Mahua (Madhuca indica), Tendu leaves (Diospyros melanoxylon) and other medicinal plants. Local people collect the NWFPs from the area and sell it to the companies and in the market.

\subsection{Sheopur district}

It is located in the northern part of Madhya Pradesh. The district is well connected by road and by a railway network. Some of the main locations are Vijaypur, Karahal and Baroda. Sheopur houses wood carvers who with great sensitivity and skill transform different varieties of wood into carvings. The crafts persons of Sheopur make pipes, masks, toys, doors, stands, windows, wooden memorials, flower vases, bedposts and cradle posts and so on [9]. 
The forest division of Sheopur is surrounded by dense forest area. The environment is ideal for all types of NWFPs and the dwellers (more than 70\%) are totally dependent on the forest for their livelihood. The villagers collect NWFPs from the forest and are sometimes engaged in labour work. Some villagers also cultivate NWFPs in their farms. All villagers are faced with lack of money for seeds, water resources and fertilizers.

\subsection{Relevance of the study}

\section{DISCUSSION OF RESULTS}

There is increasing awareness and concern about the sustainable economic development of the FDs in general. Today it is one of the challenges faced by Indian society. The production forestry was the foremost important objective in India till recent past. However, there is a shift in focus to make the forestry people oriented. The importance and role of NWFPs in the economic welfare of the FDs have been recognized and given due emphasis. There are a number of valuable NWFPs that represent opportunities for FDs to supplement their incomes. Kim and Craig have cited [10] in their paper that according to the United Nations Food and Agriculture Organization [11], it has been estimated that $80 \%$ of the population of the developing world use NWFPs to meet some of their health and nutritional needs. Several million households worldwide depend heavily on NWFPs for their income [12]. The estimated total value of world trade in NWFPs is approximately US\$1,100 million [13]. Now, the importance of NWFPs is being rediscovered. Forests are being valued not simply for their timber, but as intricate systems capable of sustained generation of diverse resources and services. NWFPs have substantial environmental, economic and cultural impact. Taking this into consideration efforts have been augmented by governmental and nongovernmental agencies in the recent past for the promotion of NWFPs as a major source of enhancing the hood of the FDs in India. Thus FDs have started to recognize the need to protect and enhance the productivity of the forest, instead of just exploiting it in an unsustainable way. In fact the primary collectors are mainly exploited on two fronts, namely in terms of (1) distress sale and (2) lack of value addition skill, awareness and/or appropriate technology for value addition and also financial support to acquire the technology. All this is resulting in destructive harvesting practices and thus is damaging the natural forests. The full potential of the NWFP as a major source for livelihood can be achieved only if all necessary inputs such as finance and institutional and technical support are provided. Need for finances are of utmost importance for the adoption of appropriate primary level technologies to enhance the value addition to forest produce, particularly NWFPs. Due to lack of access to financial assistance for adapting appropriate technology for enhancing the income levels, the FDs continue to exploit the forests for their sheer needs in an unsustainable manner. Therefore, extending microfinance to FDs for commencing NWFP based microenterprise will result in enhanced income levels for them. Simple value additions through microenterprises [14] enhance the income levels of FDs.

The easy accessibility, lack of collateral and timely availability of finance is the most important prerequisite for mitigating distress sale by NWFPs and hence the role of microfinance becomes critical for the economic welfare of the FDs.

The major NWFPs found in the study area include Aswagandh, Isopgol, Kullu gum, Salai gum, Aonla, Baheda, Mahua flower, Mahua Gulli, Satawar, Honey, Bel, tamarind and so on. The NWFPs that are suitable for value addition and can be taken up by a small group (self-help groups or village forest committees (VFCs)/forest protection committees (FPCs) at the village community level are discussed. The microfinance required for adopting such value addition practices are also worked out in this study. 


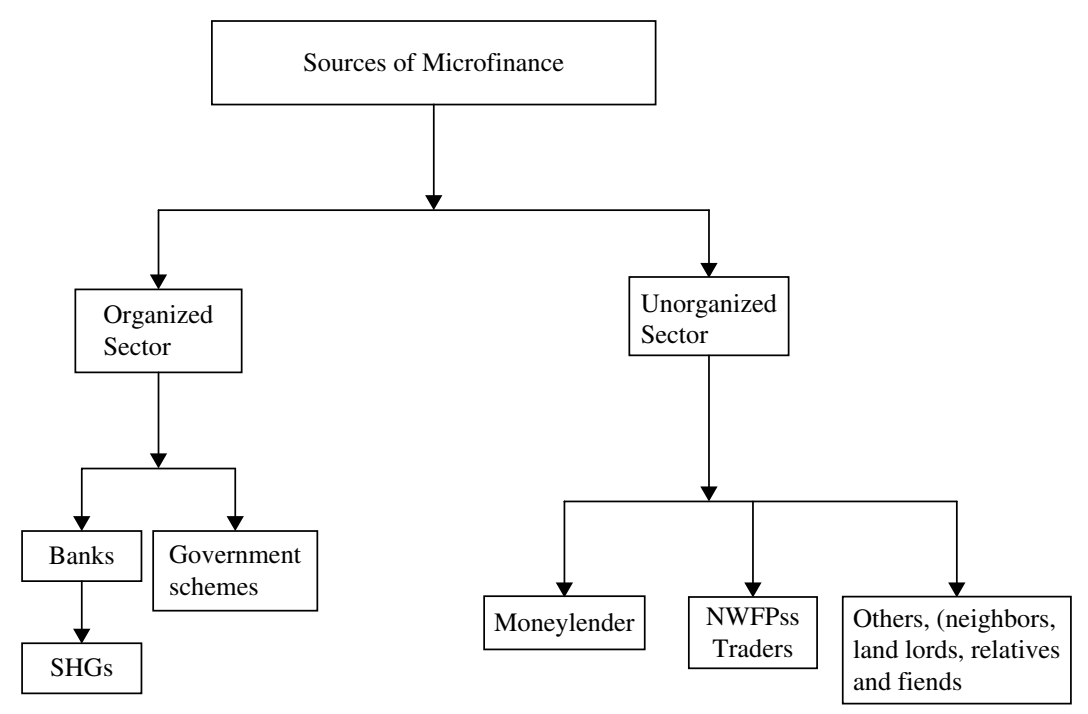

Figure 2: Microfinance sources.

Successful implementation and adoption of large scale microfinance is a complex tool for any one discipline and so the topic was studied with an interdisciplinary team to look for further refinement under the National Afforestation and Eco-Development Board (NAEB). The same concept of microfinance is fit for implementation of the plantation, pasture development and watershed projects in India where people's participation and finance can be interlinked [15].

Poverty amongst the FDs in the study area was quite obvious as the team visited areas categorized as 'backward'. It was observed by the team that FDs in the study area were desirous of improving their economic conditions. This is the first essential requirement for any value addition development program for NWFPs in the study area. The FDs earn their livelihood availing the limited opportunities that crop up within the ambit of available resources and inherent acumen. They require financial aid as available to other members of the society for meeting their requirements relating to livelihood, which include production and consumption purposes. Hence, enhancing easy accessibility and availability of microfinance can address this problem. This would include extending/operating appropriate institutional financial systems such as self-help groups (SHGs) [16], where 10-20 poor households especially women among the FDs could join together voluntarily to save for serving their financial requirements, providing credit and insurance services at their doorstep. As already proved in other parts of the country microfinance has been emerging as a powerful tool to initiate economic and social transformation amongst the poor in the study area.

\subsection{Sources of existing microfinance in the study area}

As depicted in the Fig. 2 the major sources of microfinance available to the FDs in the study area include moneylenders, NWFP traders, government schemes/grants, big landlords, primary cooperative societies, SHGs and in some cases relatives and friends. In addition to these sources in Sheopur district IIFM, Bhopal, under the Department of Science and Technology (DST - Government of India agency), and Tata Project(s) [17] is extending microfinance to the FDs and the uniqueness of 
Table 2: Sources of microfinance for FDs in the study area.

\begin{tabular}{|c|c|c|c|c|c|c|c|c|}
\hline \multirow[b]{3}{*}{$\begin{array}{l}\text { Source of } \\
\text { microfinance }\end{array}$} & \multicolumn{8}{|c|}{ Name of the district } \\
\hline & \multicolumn{2}{|c|}{ Katni } & \multicolumn{2}{|c|}{ Mandsour } & \multicolumn{2}{|c|}{ Sheopur } & \multicolumn{2}{|c|}{ Total } \\
\hline & Score* & $\begin{array}{l}\% \text { of } \\
\text { score }\end{array}$ & Score* & $\begin{array}{l}\% \text { of } \\
\text { score }\end{array}$ & Score* & $\begin{array}{l}\% \text { of } \\
\text { score }\end{array}$ & Score* & $\begin{array}{l}\% \text { of } \\
\text { score }\end{array}$ \\
\hline $\begin{array}{l}\text { Moneylender/ } \\
\text { NWFP trader }\end{array}$ & 46 & 63.8 & 32 & 39.5 & 43 & 51.6 & 121 & 52.8 \\
\hline $\begin{array}{l}\text { Banks/ } \\
\text { government } \\
\text { schemes/grants }\end{array}$ & 3 & 4.2 & 15 & 18.5 & 9 & 11.8 & 27 & 11.8 \\
\hline SHG & 11 & 15.3 & 19 & 23.5 & 5 & 6.6 & 35 & 15.4 \\
\hline $\begin{array}{l}\text { Relatives and } \\
\text { friends/others }\end{array}$ & 12 & 16.7 & 15 & 18.5 & 19 & 30.0 & 46 & 20.0 \\
\hline Total & 72 & 100 & 81 & 100 & 76 & 100 & 229 & 100 \\
\hline
\end{tabular}

Source: Estimated based on field survey 2002-2003* score-individual responses for a particular source for meeting microfinance requirement including multi-responses.

this intervention is allowing the FDs to repay the loan in kind (NWFPs) at the convenient time/ NWFP harvest season.

The survey of the study area relating to the sources of microfinance for FDs has been analyzed and presented in Table 2.

From Table 2 it can be interpreted that, in all three districts of the study area, moneylenders/ NWFP traders are the major source of microfinance for FDs/local poor people, accounting for $52.8 \%$ of the total microfinance needs on an average, followed by relatives and friends/others accounting for $20.0 \%$, SHG accounting for $15.4 \%$ and the remaining $11.8 \%$ accounted for by banks/government schemes.

In Mandsour district the moneylender is the major source of microfinance, accounting for $39.5 \%$, followed by SHG 23.5\% and relatives and friends/others and banks/government schemes/grants $18.5 \%$ each. In Mandsour district despite SHG movement people prefer to get microfinance from the moneylender due to a reasonable rate interest i.e. $2-3 \%$ per month and easy accessibility and almost no formalities.

In Katni and Sheopur districts also moneylenders/NWFP traders account for the major share 63.8 and $56.8 \%$ of microfinance sources, respectively. This is followed by sourcing from relatives and friends/others, which accounts for $16.7 \%$ in Katni and 25\% in Sheopur district, whereas SHGs account for only $15.3 \%$ in Katni district and $6.6 \%$ in Sheopur. In Sheopur district IIFM has also extended microfinance in a limited way through its action research program, which is subsumed within the head of 'others' for this district only.

It was observed in the study area that the respondents had not yet availed microfinance for production purposes. It was utilized mainly for consumption purposes.

\subsection{Purpose for which microfinance is required}

From the Table 3 it can be inferred that the main purposes of microfinance to the local people in the study area under consumption category are for health and subsistence reasons, which account for 
Table 3: Purpose of microfinance for the local people (FDs) in the study area.

\begin{tabular}{lcc}
\hline Purpose & Score* & \% of score \\
\hline Subsistence & 64 & 21.5 \\
Health & 69 & 23.2 \\
Education & 45 & 15.2 \\
Pilgrimage & 30 & 10.1 \\
Marriage & 54 & 18.1 \\
Others & 35 & 11.9 \\
Total & 297 & 100.0 \\
\hline
\end{tabular}

Source: It is estimated/reckoned based on field survey 2002-2003* that the respondents take microfinance loan for multipurposes, and hence score is used.

Table 4: Awareness about SHG and membership held.

\begin{tabular}{|c|c|c|c|c|c|c|c|c|c|}
\hline \multirow{3}{*}{$\begin{array}{l}\text { Name of } \\
\text { the district }\end{array}$} & \multirow{3}{*}{$\begin{array}{l}\text { No. of } \\
\text { respondents }\end{array}$} & \multicolumn{4}{|c|}{ Awareness of SHG } & \multicolumn{4}{|c|}{ Membership held } \\
\hline & & \multicolumn{2}{|c|}{ Aware } & \multicolumn{2}{|c|}{ Not aware } & \multicolumn{2}{|c|}{ Yes } & \multicolumn{2}{|c|}{ No } \\
\hline & & No. & $\%$ & No. & $\%$ & No. & $\%$ & No. & $\%$ \\
\hline Katni & 57 & 42 & 73.7 & 15 & 26.9 & 11 & 19.3 & 46 & 80.7 \\
\hline Mandsour & 34 & 29 & 95.3 & 5 & 4.7 & 29 & 82.9 & 5 & 17.1 \\
\hline Sheopur & 52 & 23 & 44.2 & 29 & 55.8 & 12 & 23.0 & 40 & 77.0 \\
\hline Total & 143 & 94 & 65.7 & 49 & 34.3 & 52 & 36.4 & 91 & 63.6 \\
\hline
\end{tabular}

Source: Estimated based on field survey 2002-2003.

23.2 and $21.5 \%$, respectively, of the microfinance availed. This is followed by marriage purpose accounting for $18.1 \%$, and education accounting for $15.2 \%$. The respondents stated that they also needed microfinance for the purpose of undertaking pilgrimages, which account for $10.1 \%$. The other purposes such as observing rituality and so on account for $11.9 \%$.

\subsection{Awareness about SHG and membership held}

From Table 4 it can be inferred that total awareness about SHG movement amongst the FDs in the study area is $65.7 \%$, which is impressive. But there is significant gap between awareness about SHG and membership held by the villagers in the study area; although overall awareness is $65.7 \%$, only $36.4 \%$ having membership in SHGs. It is this deficit that governmental and nongovernmental agencies should make good by efforts to promote SHG membership amongst the people who were aware but have not yet become members of any SHG. In Mandsour district the awareness rate about SHG movement was high at 95.3\%, whereas it was low in Sheopur (44.2\%). However, in Sheopur district, VFC/ FPCs have begun to function as SHG with support from forest department and IIFM, action research project. Efforts are also ongoing to formulate SHG by various government departments and agencies under different schemes. It can be concluded that the high awareness about SHGs (95.3\%) and more percentage of SHG membership (82.9\%) in Mandsour have led to reduced dependency of local people on moneylenders/NWFP traders for microfinance in comparison with Katni and Sheopur. 
Table 5: Prevailing interest rates for microfinance in the study area.

\begin{tabular}{lcccc}
\hline & \multicolumn{4}{c}{ Rate of interest per month (\%) } \\
\cline { 2 - 5 } Source of microcredit & Katni & Mandsour & Sheopur & Average \\
\hline Moneylender/NWFP trader & $3-5$ & $2-3$ & 5 & 3.83 \\
Banks & 1 & 1 & 1 & 1 \\
SHG & $2-3$ & 2 & 2 & 2.2 \\
Relatives and friends/others & 2 & 2 & 2 & 2 \\
\hline
\end{tabular}

Source: Estimated based on field survey 2002-2003.

Table 6: Average size, frequency of SHG meetings and contribution per meeting in the study area.

\begin{tabular}{llll}
\hline Name of district & Katni & Mandsour & Sheopur \\
\hline Average size of the group & 14 & 13 & 11 \\
Frequency of meeting & Monthly & Monthly & Monthly \\
Contribution for meeting per member (rupees) & $10-50$ & $20-50$ & 10 \\
\hline
\end{tabular}

Source: Estimated based on field survey 2002-2003.

\subsection{Prevailing interest rates for microfinance in the study area}

The attributes of microfinance products have to be based on the requirements of the FDs pertaining to the amount, duration of loan and rate of interest. It was observed that the FDs are getting part of their required microfinance from the moneylender but the interest rates charged by them are high, generally ranging from 5 to $10 \%$ per month even after taking land/ornaments as collateral. Prevalent interest rates for microfinance requirements in the study area are discussed in the Table 5. Currently the entire microfinance sector in India is concentrating on value addition projects commonly from non-farm sectors except in cattle financing. Table 5 depicts interest rates that are prevalent in the study area. From this table it can be inferred that the highest interest rate is charged by moneylenders/ NWFP traders; the average rate charged by them is estimated to be $03.83 \%$ per month. When asked, the FDs responded that they pay this high rate of interest due to easy accessibility and lack of alternative sources to finance their urgent needs. The average rate charged by the SHG is estimated to be $02.2 \%$ per month, which is comparatively lower. Moreover interest paid by the SHG members is added to the corpus of their own SHGs. Relatives and friends/others also cater to the microfinance needs of each other in the villages for which the average interest rate prevalent is $02 \%$ per month. This method many a times is based on reciprocal practice. The interest rate charged by banks is invariably decided by the concerned bank as per the Reserve Bank of India (RBI)/NABARD directives and extant policies. The average bank interest rate as mentioned by respondents is around $1 \%$ per month but its accessibility is very limited.

3.6 Average size, frequency of SHG meetings and contribution per meeting in the study area

From Table 6, it can be inferred that the overall average size of the SHG is 12 members, though the maximum number of members per SHG could go up to 20. The frequency of SHGs meeting is once 
in a month, but increasing the frequency of meeting to once a fortnight or a week may help the FDs in the study as it would inculcate more savings habit as observed from the practices prevailing in the other states. The average contribution per member per meeting varies from Rs. 10 to 50 in some different groups.

\subsection{Performances of SHGs and interventions required}

It was observed that a good number of SHGs has been constituted in the study area, but the rate of bank linkages is very less. Hence, the SHG members should strive to meet the bank requirements such as successful survival of SHG for at least six months and the associated GOs and NGOs should pay attention to this aspect beyond mere formation of a SHG. It was informed that such SHGs were formed with the help of government officials under government schemes such as SJRY (Swarna Jayanti Rojgar Yojana - a government scheme), Rajiv Gandhi watershed mission, and so on. Such groups started collecting their savings and depositing the same into a bank. However it was observed that the government officials after meeting their target of formation of SHGs were not interested to act as motivators and this eventually led to discontinuation of SHG. It was observed in the study area that the SHGs formed by local NGOs or by local villagers committee have better chance of continuance. The villages that have VFCs should convert them into SHGs.

The team was told that the FDs had adopted a proper system for the formation of SHG and every member was depositing equal amount of Rs. 10/- per month.

The members were having monthly periodic meetings to execute various transactions and discuss any pertinent issue. There were three office bearers viz. president, vice-president and secretary for each SHG. The team noticed that all SHGs had opened a joint bank account in their area bank. As per norms a minimum six months continuous existence of SHG is necessary to avail the advantage of NABARD's microfinance scheme for getting cheaper finance available through SHGs' bank linkage scheme. It is in this context that institutions such as SHGs and their linkage with the banks become very important. The SHGs in the study area were promoted generally by government officials and also by catalyst organizations such as the bank operating in the area or an NGO working for betterment of the FDs. The team felt that the institutional intervention, particularly for taking responsibility of supporting and guiding the SHGs in the initial stage, needs to be further enhanced to make these SHGs sustainable in the long run. The challenge facing all agencies concerned with the upliftment of the FDs including bankers is to make microfinance movement a success. The team had observed that most of the FDs were not able to reap the benefits of various government rural development schemes due to lack of awareness and lack of confidence to communicate with banks/ government officials about outstanding loans of FDs with the local moneylenders.

It was observed in the field that whatever little NWFP value additions were being carried out by FDs was largely based on indigenous technology. This is not very cost effective and advantageous. Moreover, they do not possess sufficient resources and lack the technical and managerial skills in the NWFP value addition process. They are not in a position to operate at the minimum threshold or benefit from the economies of scale. It was also observed that these FDs had been borrowing money from the local moneylenders and landlords mainly for meeting their consumption needs and not for investing in NWFPs value additions process.

Enquiry about prevailing market prices in up-country markets, for the NWFPs they are selling, have shown total ignorance as the FDs could sell only in the local markets. It was also noticed that there was an immediate need to enhance their technical skill. However suggestions of improved technology, except for tapping the gum collection process showed that they have some inherent resistance in adopting improved technology. Moreover there is also a need for an organization to 
take-up capacity building in a big way to enhance NWFP productivity of FDs. They do not have the information about the skill to increase the operations scale and improve the productivity by deploying new and better technology. The team felt that there was an immediate need to make the FDs aware about the accessibility of microfinance and ways and means for increasing the economies of scale by adopting appropriate new technology with the help of microfinance. The basic emphasis should be on production loan and there has to be a gradual shift from existing consumption driven microfinance loans from moneylenders to production driven microfinance loans from SHG-bank linkage program.

While interacting with the bank officials of the study area, the team gathered that the bank officials were eager to provide the financial linkages to active SHGs. However the problem area is how to convert the existing defunct SHGs to active SHGs. Therefore, the challenge lies in making these SHGs active and effective so that the further SHG-bank linkage programs can be pursued.

During the field discussions regarding informal channels of microfinance, the team members were told that the FDs were neither aware of sources such as chit-funds/nidhis (informal sources of finance) nor was any such activity noticed in the study area. However, it was noticed that the most predominant provider of microfinance (who account for large volume to the total microfinance requirements of the study area) are the local traders, who combine the sale of provisions of daily use with microfinance to the FDs. These traders usually charge exorbitant rates of interest on the lending to the FDs. In addition to local traders there are a good number of larger farmers who are in the business of moneylending to the FDs. It was also noticed in the study area that the local traders were buying the NWFPs from FDs at distress price. No system that can help the FDs in selling NWFPs in up-country markets for better price even on commission basis has been found. Similarly the team also could not come across any brokerage system that brings the actual buyers (NWFPs traders) in contact with the actual sellers (i.e. the FDs).

While interacting with the respondents, most of them opined that the accessibility to microfinance is the major problem, despite at the high interest rates. It was mentioned that formal banking system was not amenable to them due to absence of required collateral or regular and stable employment opportunities, which otherwise would have ensured timely re-payment of their installments to the banks. Thus, traditional local moneylenders and traders continue to play a major role in meeting their microfinance requirements.

Therefore, it is becoming apparent that the SHG moment has to be revitalized in the area and the advantage of the NABARD scheme of SHG bank linkages need to be promoted. This scheme is based on social collateral instead of physical collateral for availing bank finance. The team felt that there is need for institutional intervention (NGOs, Joint Forest Management committee, etc.) in the entire study area for taking up such revitalization. Formal microfinance institutions have not yet extended their activities in Madhya Pradesh in general and to the study area in particular. Hence it becomes imperative to attract leading microfinance institutions to extend their activities in these areas either through the extension of their territory or by starting new institutions in the study area.

The majority, i.e. about $55 \%$ of the respondents, has mentioned that if they were given an easy access to the microfinance on nominal interest rate (not subsidized), they would be able to set up small enterprises based on the locally available resources mainly NWFPs. They could be sure that they would earn sufficiently to repay the loan installments in time. To the team also, this appears to be a realistic alternative for increasing income of the FDs. If, forward marketing linkages are also established along with the microfinance, the success of such established enterprises would be ensured. However, the team has not found any such attempt by the FDs to take up NWFP based microenterprise in the study area. 
As the demand for microfinance would be mainly from poor FDs who live in scattered hamlets it would lead to the higher operating cost for microfinance institution especially during the initial phase. Therefore, it is important that one should not expect the microfinance activities to break even from inception. It requires sufficient financial and institutional support at least for the gestation period. Efforts are also to be made to convince the FDs not to default or leniency in ensuring timely repayments would encourage more members to default, which would jeopardize the entire microfinance momentum.

The team noticed that the FDs, particularly women were interested in saving products, which suit their saving potential and schedule preferably on weekly basis. Therefore it is equally important to give the similar emphasis to the saving products as the credit products. The encouragement for mobilizing the savings from FDs and the same as credit to the needy members will enhance the viability of microfinance movement since the savings will be the cheapest mode of augmenting the required finance. However, the team was told by the FDs that they had saved money in the SHG movement, which was started about two years ago (2002) in the study area. However, subsequently, most of the members had withdrawn their money and therefore, no further activity of SHG could take place and they were feeling insecure due to inability to save. The majority of the respondents mentioned during field survey that they themselves were not able to maintain accounts relating to savings and loans and also other records due to illiteracy and hence depend on external assistance.

The formal microfinance institutions under the present regulatory system cannot mobilize the savings from the FDs. Therefore, the SHG bank linkage of microfinance appears to be more suitable in the study area. The SHGs, being grassroot level organizations, have comparatively much lower cost of lending to the formal banking system. Thus SHG bank linkage model will provide an outlet for banks for lending purpose and at the same time overcome the likely enhanced cost of operations due to scattered clientele. Moreover the individual loan request (may be verbal) can be processed in a more objective way by SHGs due to their proximity to assess the genuineness of the borrower along with his/her potential for timely repayment of the loan installment.

The team observed that the bankers were not very keen to finance SHGs directly due to their apprehensions about security of their funds. Therefore need is felt for institutional intermediation between the banks and SHGs. This can be filled by NGOs very appropriately in the study area. However, when the team visited the Chambal Rural Grameen Bank, Virpur, in Sheopur District, it was mentioned by the branch manager that their bank is now encouraging the villagers to revitalize SHGs and also form new SHGs, in order to ensure their bank was providing the facility of NABARD's scheme of SHG-bank linkage.

In addition to NABARD's scheme, the other wholesalers microfinance institutions (MFIs) and agencies such as Rashtriya Mahila Kosh (RMK), New Delhi, Friends of Women' World Banking (FWWB) in Ahmedabad and some NGOs supporting SHG Federations such as PRADAN in Madhya Pradesh can be contacted to augment the microfinance activities in Madhya Pradesh for FDs.

\subsection{Catalyst role of NGOs}

It is envisaged that with the involvement of NGOs in the study area it is possible to inculcate financial discipline amongst the FDs by mobilizing their savings and making the SHGs active. Therefore banks can be attracted for providing microfinance in the study area. The NGOs would also be helpful in building social pressure for regular payment of installments, which would further encourage banks to increase their lending to the SHGs. The actual management of SHGs could continue to be in the hands of FDs especially women thereby increasing the success of the movement. Therefore, there will be the involvement of major stakeholders in the entire operation of this microfinance 


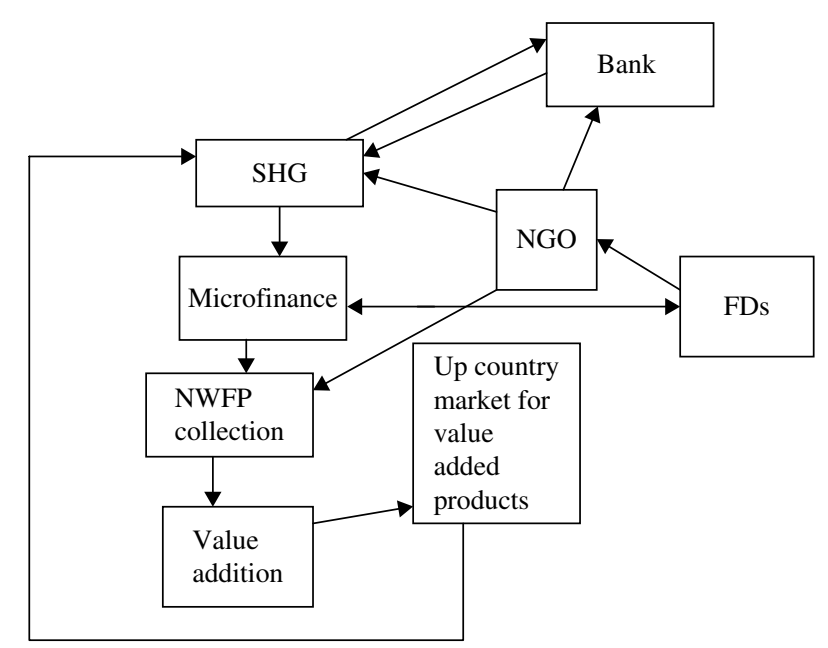

Figure 3: The role of NGO as catalysts/facilitators in promoting microfinance.

program and thus it would become a successful program. It is envisaged that the successive credit requirements of the FDs is bound to increase due to enhancement in their entrepreneurial skills. Therefore, the microfinance system should also be flexible enough to accommodate enhanced credit requirements in future (Fig. 3).

It was experienced by the team during field survey that for the FDs, in addition to the credit, it would be better if some services, particularly marketing support for value added products, are provided by the NGOs; this can certainly ensure the success of the small enterprise.

\subsection{Growing SHG movement}

Though the respondents do not have sufficient surplus for savings they are eager to save even a minimum amount that is made at their doorstep. The FDs also mentioned that they would cut down their existing daily expenses in order to contribute to the savings. The SHG movement is growing especially under the quantitative target oriented approach adopted by various government schemes in the study area as shown in Table 7. From this table it can be inferred that in Mandsour district the total number of groups formed under sundry government schemes is 3837 of which women SHGs account for $42 \%$. In Katni district the total number of groups is 3336 and women groups account for $40.4 \%$ whereas in Sheopur district the total number of groups is 1674 and women groups account for $38 \%$. By and large in the study area women groups account for $40 \%$ of the SHGs.

From Table 8, it can be inferred that SHG movement in Mandsour district has a very impressive number of SHGs accounting for 3\% of total SHGs in MP state, and with bank linkage for 23 groups, with a total group savings of Rs. 38.16 lakhs, followed by Katni district accounting for $1.33 \%$ of total SHGs. Bank linkage exists for 13 groups with a total group savings Rs. 5.61 lakhs. SHG movement is yet to take place in Sheopur district. Efforts should be geared up for linking the remaining groups with banks. A committed NGO would be of great help in doing so.

The approach, which one should adopt, focuses on those FDs who are poorest among poor so that they can also join the main stream of development. In this direction, generating livelihood themselves with microfinance as the major tool would be beneficial. This microfinancial assistance can 
Table 7: SHGs formed under various schemes in the study area.

\begin{tabular}{|c|c|c|c|c|c|}
\hline $\begin{array}{l}\text { Serial } \\
\text { no. }\end{array}$ & Particulars & $\begin{array}{l}\text { Mandsour } \\
\text { (no. of } \\
\text { groups) }\end{array}$ & $\begin{array}{l}\text { Sheopur } \\
\text { (no. of } \\
\text { groups) }\end{array}$ & $\begin{array}{c}\text { Katni } \\
\text { (no. of } \\
\text { groups) }\end{array}$ & $\begin{array}{c}\text { MP state } \\
\text { (no. of } \\
\text { groups) }\end{array}$ \\
\hline \multirow[t]{3}{*}{1} & Under SGSY & & & & \\
\hline & Total SHGs & 2,586 & 1,120 & 2,060 & 121,643 \\
\hline & Women SHGs & 520 & 226 & 341 & 52,490 \\
\hline \multirow[t]{3}{*}{2} & Under SJSRY & & & & \\
\hline & Total SHGs & 20 & 4 & 8 & 1,698 \\
\hline & Women SHGs & 20 & 4 & 8 & 1,698 \\
\hline \multirow[t]{3}{*}{3} & Under DWC\&D & & & & \\
\hline & Total SHGs & 957 & 105 & 275 & 27,556 \\
\hline & Women SHGs & 957 & 105 & 275 & 27,566 \\
\hline \multirow[t]{3}{*}{4} & $\begin{array}{l}\text { Under Watershed } \\
\text { Mission }\end{array}$ & & & & \\
\hline & Total SHGs & 180 & 30 & 275 & 19,601 \\
\hline & Women SHGs & 45 & 9 & 218 & 7,527 \\
\hline \multirow[t]{4}{*}{5} & Under Padna & & & & \\
\hline & Badna Adolan & 79 & 413 & 706 & 57,204 \\
\hline & Total SHGs & 55 & 290 & 495 & 40,091 \\
\hline & Women SHGs & & & & \\
\hline 6 & $\begin{array}{l}\text { Agriculture } \\
\text { department }\end{array}$ & 15 & 2 & 12 & 1,781 \\
\hline 7 & $\begin{array}{l}\text { Others (including } \\
\text { forest department) }\end{array}$ & & & & 2,033 \\
\hline \multirow[t]{2}{*}{8} & Total SHGs & 3,837 & 1,674 & 3,336 & 229,483 \\
\hline & Women SHGs & 1,612 & 636 & 1,349 & 131,086 \\
\hline 9 & $\begin{array}{l}\text { Number of blocks } \\
\text { in the district }\end{array}$ & 5 & 3 & 6 & 313 \\
\hline \multirow[t]{3}{*}{10} & $\begin{array}{l}\text { Average number of } \\
\text { the SHGs per block }\end{array}$ & & & & \\
\hline & Total & 767 & 558 & 556 & 733 \\
\hline & Women SHGs & 322 & 213 & 225 & 419 \\
\hline
\end{tabular}

Source: Records office of the director, SHGs MP state, Bhopal, provided by NABARD officials (2002-2003).

be catered through (a) SHG-bank linkage program - a scheme of NABARD, (b) MFIs, (c) action (IIFM project in Sheopur district) research funded by donor agencies and also (d) VFCs/FPCs.

\section{CONCLUSIONS AND RECOMMENDATIONS}

The FDs are striving to sustain livelihood with the help of available local resource dovetailing their inherent acumen and opportunity. They require financial resource as members of the society for meeting their requirements relating to livelihood, which include production and consumption purposes. Hence, making provisions for easy accessibility and availability of microfinance would 
Table 8: SHG movement in the study areas.

\begin{tabular}{|c|c|c|c|c|c|}
\hline $\begin{array}{l}\text { Serial } \\
\text { no. }\end{array}$ & Particulars & $\begin{array}{l}\text { Mandsour } \\
\text { (no. of } \\
\text { groups) }\end{array}$ & $\begin{array}{c}\text { Sheopur } \\
\text { (no. of } \\
\text { groups) }\end{array}$ & $\begin{array}{c}\text { Katni } \\
\text { (no. of } \\
\text { groups) }\end{array}$ & $\begin{array}{c}\text { MP state } \\
\text { (no. of } \\
\text { groups) }\end{array}$ \\
\hline 1 & Total number of SHGs & 1,366 & 0 & 607 & 45,486 \\
\hline 2 & Total number of members & 14,747 & 0 & 6,490 & 466,043 \\
\hline 3 & Total women SHGs & 996 & 105 & 607 & 45,300 \\
\hline 4 & Total women members & 11,044 & 1,928 & 6,490 & 466,043 \\
\hline 5 & $\begin{array}{l}\text { Total savings } \\
\text { (in lakhs of rupees) }\end{array}$ & 38.16 & 0 & 5.61 & $1,088.1$ \\
\hline 6 & $\begin{array}{l}\text { Number of total units } \\
\text { linkages with banks }\end{array}$ & 23 & 0 & 13 & 3,729 \\
\hline 7 & $\begin{array}{l}\text { Bank linkage/loan received } \\
\text { (in lakhs of rupees) }\end{array}$ & 15 & 2 & 12 & 1,781 \\
\hline
\end{tabular}

Source: Document of MP Women Economic Development Corporation, Bhopal.

relieve the FDs from exploitation. Currently, FDs are meeting a major part of their loan requirement through moneylenders. The interest rates charged by the moneylenders are very high ranging from 5 to $10 \%$ per month, even after providing land/ornaments as collateral for the money borrowed. Effective implementation of microfinance programs in the areas will check the high interest rates charged by the moneylenders. Provisions for small loans without insistence of physical collateral through SHGs would help the FDs undertake local resource (NWFPs) value additions and inculcate savings habits. Mostly FDs are compelled to sell their NWFPs harvest at a very low price for want of money during phases when they do not have any other alternative source of livelihood.

SHGs movement in Mandsour district is gaining momentum. The Mandsour district alone accounts for 3\% share of total SHGs in MP state, and 23 SHGs have linked with banks, resulting in total group savings of Rs. 38.16 lakhs. In Katni district the SHGs account for a share of $1.33 \%$ with 13 groups having linkages with banks and generating total group savings of Rs. 5.61 lakhs. The movement is yet to take place in Sheopur district. Hence, it is recommended that the concerned governmental agencies initiate necessary action for effective promotion of SHG movement in the study area. A committed NGO would be of great help in promoting such SHG movement.

In the study area moneylenders/NWFP traders are found to be a major source of microfinance for FDs, accounting for on an average $52.8 \%$ of the total microfinance needs. The main purpose of microfinance to the FDs in the study area is for health and subsistence purposes.

There is a significant gap between awareness about SHGs and membership held by the FDs in the study area. Though overall awareness rate was $65.7 \%$, only $36.4 \%$ people were having membership in SHGs. Hence, the governmental and nongovernmental agencies should enhance efforts to bridge the gap. At the disaggregate level, Mandsour district has greater rate of awareness (95.3\%) whereas it is low in Sheopur. In Sheopur district VFC/FPCs have begun to function as SHG with support from the forest department and IIFM action research project and efforts are also on to organize SHGs by various other governmental departments and agencies under different schemes.

It was observed in the study area that SHGs that were formed under various government schemes such as the Rajiv Gandhi watershed mission, SGSRY and so on have become defunct, as government 
officials who were the catalyst for forming such SHGs were aiming to meet their authenticities targets organized to them for formation of the SHGs and FDs were not able to identify themselves with such SHGs. Hence, SHGs in the study area should be formed preferably with the help of local NGOs or by local villager committees, to ensure their survival. The villages with VFCs/FPCs should try to widen the VFCs/FPCs scope to include SHG activities. The approach is recommended is to be focused on those FDs that are poorest among poor so that they can also join the mainstream of development for generating a livelihood themselves with the help of microfinance. This microfinancial assistance can be further strengthened through (a) SHG-Bank linkage program - a scheme of NABARD and (b) MFIs helping such SHGs.

It was observed in the field and corroborated by the data that the existing SHGs do not have sufficeint funds for rotating among themselves and hence they required financial support from outside. Therefore, it is recommended the concerned GOs and NGOs should work hard to link the SHGs with banks under NABARD's scheme so that enough funds can be made available to such SHGs.

During the discussion with bank officials in the study area, it was observed that they were reluctant to link the SHGs mainly questioning the credit worthiness and fianancial viability of these SHGs. Therefore, it is recommended that the bankers should be encouraged to enhance their lending to SHGs by involving NGOs as intermediaries between banks and SHGs. The bank officials also have to be trained so that they can provide loans without physical collateral to SHGs and rely on social collateral of SHGs. In addition the banks should also develop local need based tailormade saving and credit products that are suitable to the needs of the FDs.

At the policy-making level, the microfianance and NWFPs should be dovetaileld with an apex cell, which can be under the Mininstry of Environment and Forests or the Ministry of Tribal Affaris, Government of India. The apex cell can help the FDs in designing of NWFPs, promotion of sale and NWFPs extending microfinance for NWFPs value addition. Such an apex cell is also expected to work for advocay of microfianance for NWFP value addition and also encouraging effective networking among NGOs, banks, local villagers and various government departments and agencies.

The interest charged by banks on microfianance loans to SHGs could be a part of the funds spent on providing subsidies under various tribal development government sponsored programs that may give impetus to FDs to form SHGs. In addtion to SHG-bank linkage system for extending microfinance to FDs, formation of special MFIs, which can directly act as microfinance delivery channels of the union government, needs to be explored. The apex cell should also take up the work of documentation of NWFPs value addition related microfinance practices that have been adopted in the country.

It is concluded that institutional network, microfinance, marketing, technology, infrastructure development and other managerial interventions have to be augmented by all concerned GOs, banks and NGOs, keeping, the local socio-economic aspects in mind, for effective and better results.

\section{ACKNOWLEDGEMENT}

The authors acknowledge sincere gratitude to Dr. Sheela Prasad, IES, advisor, Ministry of Finance, Government of India, for her help in English editorial corrections (spelling and grammar problems). The authors also express their thanks to the anonymous referees for their valuable reviews and comments. This paper is an abridged form of the authors' research project titled 'Scope of Micro Finance in the development of NWFP based activities: Case studies from Madhya Pradesh' -2003, funded by RCNAEB, IIFM, Bhopal, India. 


\section{REFERENCES}

[1] Malhotra, K.C., Quoted from MFP News, 1994: 12-15, 1992.

[2] Pethiya, B.P. \& Teki, S., Assessing the Impact of Microfinance as a Tool for Adoption of Appropriate Technology and Conserving the Environment (with Specific Reference to NWFP) IIFM, Bhopal, unpublished report, 2003.

[3] Pethiya, B.P. \& Surayya, T., Role of microfinance in marketing NWFP and improving the living standard of rural poor, IIFM. News Letter, 3(2), pp. 8-9, 2000.

[4] Anderson, C.L., Locker, L. \& Nugent, R., Micro credit, social capital, and common pool. Resources, World Development, 30(1), pp. 95, 2001 (Internet). doi:10.1016/S0305-750$\mathrm{X}(01) 00096-1$

[5] Kishanjit Basu \& Krishan Jindal, Microfinance Emerging Challenges, McGraw-Hill: New Delhi, 2000.

[6] www.basixindia.com.

[7] Kumtakar, V.A. \& Kumtakar P., Rural family poultry scenario in tribal areas of central Madhya Pradesh, India - a socio-economic analysis. Available from: http://www.fao.org/ag/againto/ themes/en/infpd/documents/econf_scope/add_paper9.html

[8] www.mapsindia.com.

[9] www.sheopur.nic.in/stat.htm.

[10] Wilkinson, K. \& Elevitch, C. Nontimber forest products: an introduction. The Overstory, 53. Available from http://www.agroforestry.net/overstory/overstory53.html 1999-2001.

[11] FAO Report, 1997.

[12] Giri, T.K., Bhattacharya, P. \& Santra, S.C., Ecology and economy of NWFPs in village lifea case from Bankura District in West Bengal, Annals of Forestry, 9(1), pp. 1-16, 2001.

[13] Shiva, M.P., Inventory of Forest Resources for Sustainable Management and Bio-Diversity Conservation [with list of multipurpose tree species yielding both timber and Non-timber Forest Products (NWFP) with shrub and herb species of NWFP importance], 1998, http:// www.angelfire.com.

[14] Reddy, A.V.S., Rural technologies for poverty alleviation, Journal of Kurukshetra, New Delhi, pp. 26, 2002.

[15] Bhattacharya, P. \& Seyed Faiz Hayat., Issues in Sustainable Management of NWFPs for Livelihood Generation of Tribals: A case from Sheopur District of Madhya Pradesh, India, Proceedings of the National Workshop on NWFP-New Mechanism and Strategies, 29-30th May, Vigan Bhawan, New Delhi, Organised by MoEF and MP MFP Federation, 2003.

[16] Dwarakanath, H.D., Rural credit and women Self Help Groups, A profile of Ranga Reddy, District in Andhra Pradesh, Journal of Kurukshetra, New Delhi, November 2002. pp. 15, 2002.

[17] Bhattacharya, P., Bhagat, N.K. \& Hayat, S.F,B., Science \& Technology Management, Intervention for Value Addition to Select NWFPs for Enhancement of Income of Local People in M.P., DST Sponsored Project Report, IIFM, Bhopal (unpublished), 1999. 